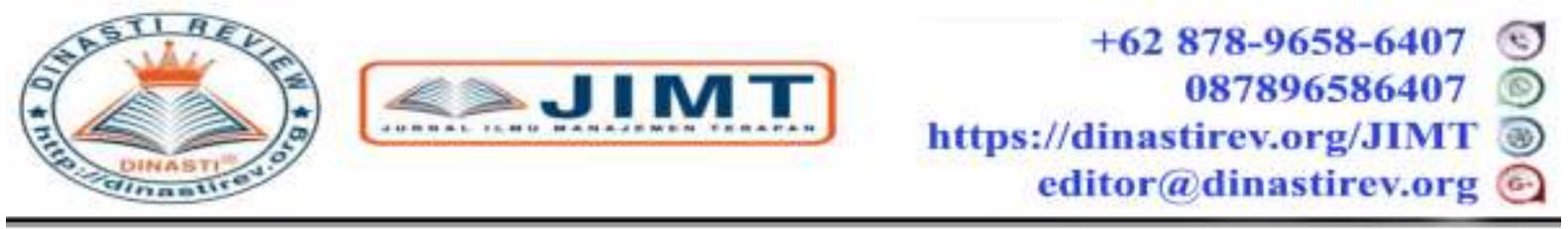

\title{
BUSINESS ETHIC AND GOOD GOVERNANCE ( BE \& GG ) ETIKA BISNIS PADA PT SUCACO Tbk
}

\author{
Harits Mufqi Arief \\ Universitas Mercu Buana, Jakarta Indonesia
}

ARTICLE INFORMATION

Received: $11 / 12 / 2019$

Revised: 21/12/2019

Issued: $31 / 12 / 2019$

(filled in by Editor)

Corresponding Author:

Letnan Delimunthe

E-mail:

haritsmufqi@gmail.com

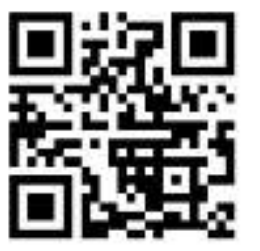

DOI:10.31933/JIMT
Abstrak: Etika bisnis merupakan cara untuk melakukan kegiatan bisnis, yang mencakup seluruh aspek yang berkaitan dengan individu, perusahaan dan juga masyarakat. Etika bisnis dalam suatu perusahaan dapat membentuk nilai, norma dan perilaku karyawan serta pimpinan dalam membangun hubungan yang adil dan sehat dengan pelanggan/mitra kerja, pemegang saham, masyarakat. Penelitian ini bertujuan untuk mendeskripsikan bagaimana penerapan kewajiban moral dan bagaimana penerapan prinsip etika bisnis pada PT SUCACO Tbk. Metode penelitian yang digunakan dalam penelitian ini adalah metode analisis deskriptif kualitatif agar dapat mendapatkan informasi dengan cermat untuk mengetahui konsep etika bisnis pada PT SUCACO Tbk.

Kata Kunci: Etika Bisnis, Deskriptif Kualitatif

\section{PENDAHULUAN}

Dalam masyarakat, manusia mengadakan hubungan-hubungan antara lain hubungan agama, keluarga, perdagangan, politik dan sebagainya. Sifat hubungan ini sangat rumit dan coraknya berbagai ragam. Hubungan antara manusia ini sangat peka, sebab sering dipengaruhi oleh emosi yang tidak rasional. manusia selalu berusaha agar tercapai kerukunan dan kebahagiaan di dalam suatu masyarakat. Munculah peraturan baik tertulis maupun tidak tertulis yang kita sebut etik, etika, norma, kaidah, tolak ukur.

Etika dapat diartikan sebagai kebiasaan yang terjadi di suatu lingkungan dan waktu tertentu. Dalam berbisnis juga terdapat etika-etika yang harus dipenuhi oleh perusahaan sebagai sarana untuk menjalankan visi misi perusahaan tersebut. Etika bisnis merupakan aplikasi pemahaman kita tentang apa yang baik dan benar untuk beragam institusi, teknologi, transaksi, aktivitas dan usaha yang kita sebut bisnis. Pembahasan tentang etika bisnis harus dimulai dengan menyediakan kerangka prinsip-prinsip dasar pemahaman tentang apa yang dimaksud dengan istilah baik dan benar, hanya dengan cara itu selanjutnya seseorang dapat membahas implikasi-implikasi terhadap dunia bisnis.

Persaingan yang ketat dalam memperoleh keuntungan yang tinggi, perusahaan menggunakan berbagai macam strategi dalam pelaksanaan bisnisnya. Etika bisnis mengatur 
batasan-batasan yang harus dipatuhi setiap perusahaan dalam menajalankan bisnisnya. Perusahaan yang meyakini bahwa prinsip bisnis baik adalah perusahaan yang menjalankan etika bisnis. Setiap perusahaan memiliki peraturan-peraturan atau kode etik yang harus ditaati oleh setiap elemenya agar dapat menunjang kelancaran kegiatan operasional perusahaan. PT SUCACO Tbk. Adalah perusahaan yang menjalankan etika bisnis dalam menjalankan bisnisnya. Dengan memberikan prioritas pada mereka dalam pengembangan profesionalisme, keseimbangan kehidupan, dan kemampuan mereka untuk berkontribusi pada perusahaan. PT SUCACO Tbk. mengelola dan mengembangkan bisnis secara bertanggung jawab dan berkesinambungan.

Tujuan dari pembuatan artikel ini adalah untuk mengetahui penerapan etika bisnis yang dilakukan oleh PT SUCACO Tbk. dalam menjalankan bisnisnya untuk mencapai visi dan misi perusahaan. Serta untuk memastikan etika bisnis yang dijalankan atau diterapkan oleh perusahaan sudah sesuai dengan norma-norma dan adat yang berlaku atau belum.

\section{KAJIAN PUSTAKA}

Definisi Etika Bisnis

Etika bisnis merupakan suatu pengetahuan mengenai tata cara ideal dalam mengelola bisnis dengan memperhatikan norma dan moralitas yang berlaku secara universal, ekonomi, dan sosial. Etika Bisnis dapat menjadi standar dan pedoman bagi seluruh karyawan termasuk manajemen dan menjadikannya sebagai pedoman untuk melaksanakan pekerjaan sehari-hari dengan dilandasi moral yang luhur, jujur, transparan dan sikap yang profesional. Tiga pendekatan dasar dalam merumuskan tingkah laku etika bisnis, yaitu:

1. Utilitarian Approach: setiap tindakan harus didasarkan pada konsekuensinya. Oleh karena itu, dalam bertindak seseorang seharusnya mengikuti cara-cara yang dapat memberi manfaat sebesarbesarnya kepada masyarakat, dengan cara yang tidak membahayakan dan dengan biaya serendahrendahnya.

2. Individual Rights Approach: setiap orang dalam tindakan dan kelakuannya memiliki hak dasar yang harus dihormati. Namun tindakan ataupun tingkah laku tersebut harus dihindari apabila diperkirakan akan menyebabkan terjadi benturan dengan hak orang lain.

3. Justice Approach: para pembuat keputusan mempunyai kedudukan yang sama, dan bertindak adil dalam memberikan pelayanan kepada pelanggan baik secara perseorangan ataupun secara kelompok.

Menurut Bertens (2000), etika bisnis lebih luas dari ketentuan yang diatur oleh hukum, bahkan merupakan standar yang lebih tinggi dibandingkan standar minimal ketentuan hukum, karena dalam kegiatan bisnis seringkali kita temukan wilayah abu-abu yang tidak diatur oleh ketentuan hukum. Terdapat tiga aspek dan sudut pandang pokok dari bisnis, yaitu:

1. Sudut pandang ekonomi, bisnis adalah kegiatan ekonomis, maksudnya adalah adanya interaksi produsen/perusahaan dengan pekerja, produsen dengan produsen dalam sebuah organisasi. Kegiatan antar manusia ini adalah bertujuan untuk mencari untung oleh karena itu menjadi kegiatan ekonomis. Pencarian keuntungan dalam bisnis tidak bersifat sepihak, tetapi dilakukan melalui interaksi yang melibatkan berbagai pihak.

2. Sudut pandang etika, dalam bisnis berorientasi pada profit adalah sangat wajar, akan tetapi jangan keuntungan yang diperoleh tersebut justru merugikan pihak lain. Maksudnya adalah, semua yang kita lakukan harus menghormati kepentingan dan hak orang lain. 
3. Sudut pandang hukum, bisa dipastikan bahwa kegiatan bisnis juga terikat dengan Hukum Dagang atau Hukum Bisnis, yang merupakan cabang penting dari ilmu hukum modern. Dalam praktik hukum banyak masalah timbul dalam hubungan bisnis pada taraf nasional maupun internasional. Seperti etika, hukum juga merupakan sudut pandang normatif, karena menetapkan apa yang harus dilakukan atau tidak boleh dilakukan.

Menurut Muslich (2004:9), pengertian etika bisnis adalah suatu pengetahuan tentang tata cara ideal pengaturan dan pengelolaan bisnis yang memperhatikan norma dan moralitas yang berlaku secara universal. Menurut Hill dan Jones, pengertian etika bisnis adalah suatu ajaran untuk membedakan antara salah dan benar guna memberikan pembekalan kepada setiap pemimpin perusahaan ketika mempertimbangkan untuk mengambil keputusan strategis yang terkait dengan masalah moral yang kompleks. Menurut Velasques, pengertian etika bisnis adalah studi yang dikhususkan mengenai moral yang benar dan salah. Studi ini berkonsentrasi pada standar moral sebagaimana diterapkan dalam kebijakan, institusi dan perilaku bisnis.

Dalam menciptakan etika bisnis, ada beberapa hal yang perlu diperhatikan, antara lain adalah:

1) Pengendalian diri.

2) Pengembangan tanggung jawab social (social responsibility).

3) Mempertahankan jati diri dan tidak mudah untuk terombang-ambing oleh pesatnya perkembangan informasi dan teknologi.

4) Menciptakan persaingan yang sehat.

5) Menerapkan konsep "pembangunan berkelanjutan".

6) Menghindari sifat 5K (Katabelece, Kongkalikong, Koneksi, Kolusi, dan Komisi).

7) Mampu menyatakan yang benar itu benar.

8) Menumbuhkan sikap saling percaya antara golongan pengusaha kuat dan golongan pengusaha ke bawah.

9) Konsekuen dan konsisten dengan aturan main yang telah disepakati bersama.

10) Menumbuhkembangkan kesadaran dan rasa memiliki terhadap apa yang telah disepakati.

11) Perlu adanya sebagian etika bisnis yang dituangkan dalam suatu hokum positif yang berupa peraturan perundang-undangan.

\section{Tujuan Etika Bisnis}

Bagi para pengusaha, tujuan etika dalam berbisnis adalah untuk meningkatkan kesadaran moral serta membuat batasan-batasan bagi para pelaku bisnis serta menjalankan good business. Para pengusaha harus memiliki pemahaman bahwa monkey business atau praktek bisnis kotor hanya akan merugikan banyak pihak, termasuk dirinya sendiri pada akhirnya.Pemahaman dan pelaksanaan etika dalam berbisnis dengan baik akan membawa suatu perusahaan ke arah manajemen bisnis yang baik sehingga memiliki citra yang baik di mata semua orang. Intinya, bisnis yang menerapkan etika berbisnis yang baik umumnya tidak akan merugikan pihak lain, tidak melanggar hukum yang berlaku, dan menjaga kondisi bisnis tetap kondusif.

\section{Manfaat Etika Bisnis}

1. Perusahaan mendapatkan kepercayaan dari konsumen.

Perusahaan yang jujur akan menciptakan konsumen yang loyal. Bahkan konsumen akan merekomendasikan kepada orang lain untuk menggunakan produk tersebut.

2. Citra perusahaan di mata konsumen baik. 
Dengan citra yang baik maka perusahaan akan lebih dikenal oleh masyarakat dan produknya pun dapat mengalami peningkatan penjualan

3. Meningkatkan motivasi pekerja.

Karyawan akan bekerja dengan giat apabila perusahaan tersebut memiliki citra yang baik dimata perusahaan.

4. Keuntungan perusahaan dapat di peroleh.

Etika adalah berkenaan dengan bagaimana kita hidup pada saat ini dan mempersiapkan diri untuk masa depan. Bisnis yang tidak punya rencana untuk menghasilkan keuntungan bukanlah perusahaan yang beretik.

\section{Prinsip Etika Bisnis}

Pada dasarnya, setiap pelaksanaan bisnis seyogyanya harus menyelaraskan proses bisnis tersebut dengan etika bisnis yang telah disepakati secara umum dalam lingkungan tersebut. Sebenarnya terdapat beberapa prinsip etika bisnis yang dapat dijadikan pedoman bagi setiap bentuk usaha. Sonny Keraf (1998) menjelaskan bahwa prinsip etika bisnis adalah sebagai berikut :

\section{Prinsip Otonomi}

Sikap dan kemampuan manusia untuk mengambil keputusan dan bertindak berdasarkan kesadarannya tentang apa yang dianggapnya baik untuk dilakukan. Jika orang sadar dalam melakukan kewajibannya dalam berbisnis maka dikatan orang tersebut sudah memiliki prinsip otonomi dalam beretika bisnis. Sebagai contoh dia paham mengenai bidang pekerjaannya dengan situasi dan tuntutan yang akan dihadapinya dan mengetahui aturan apa saja didalam bidang pekerjaannya. Selain, itu seseorang yang sudah memiliki fungsi otonomi akan sadar tentang risiko dan akibat yang akan muncul terhadap dirinya dan orang lain yang sebagai pelaku bisnis. Pada umumnya seseorang yang memiliki prinsip otonomi akan lebih menyukai diberikan kebebasan dan kewenangan untuk melakukan hal yang dianggapnya baik.

2. Prinsip Kejujuran

Terdapat tiga lingkup kegiatan bisnis yang bisa ditunjukkan secara jelas bahwa bisnis tidak akan bias bertahan lama dan berhasil kalau tidak didasarkan atas kejujuran. Pertama, jujur dalam pemenuhan syarat-syarat perjanjian dan kontrak. Kedua, kejujuran dalam penawaran barang atau jasa dengan mutu dan harga yang sebanding. Ketiga, jujur dalam hubungan kerja intern dalam suatu perusahaan. Sikap kejujuran sendiri biasanya dikaitkan dengan harga barang yang telah ditawarkan. Dalam berbisnis secara modern, kepercayaan konsumen merupakan hal yang sangat penting. Oleh sebab itu pelaku bisnis dihimbau untuk memberikan informasi yang sebenarnya terhadap para konsumen.

3. Prinsip Keadilan

Menuntut agar setiap orang diperlakukan secara sama sesuai dengan aturan yang adil dan sesuai criteria yang rasional obyektif, serta dapat dipertanggung jawabkan. Prinsip Saling Menguntungkan (Mutual Benefit Principle). Menuntut agar bisnis dijalankan sedemikian rupa sehingga menguntungkan semua pihak.

4. Prinsip Integritas Moral

Terutama dihayati sebagai tuntutan internal dalam diri pelaku bisnis atau perusahaan, agar perlu menjalankan bisnis dengan tetap menjaga nama baik pimpinan atau orang-orangnya maupun perusahaannya. 


\section{Peran Etika Bisnis}

Adapun etika bisnis perusahaan memiliki peran yang sangat penting, yaitu untuk membentuk suatu perusahaan yang kokoh dan memiliki daya saing yang tinggi serta mempunyai kemampuan menciptakan nilai (value-creation) yang tinggi, dimana diperlukan suatu landasan yang kokoh untuk mencapai itu semua. Dan biasanya dimulai dari perencanaan strategis, organisasi yang baik, sistem prosedur yang transparan didukung oleh budaya perusahaan yang handal serta etika perusahaan yang dilaksanakan secara konsisten dan konsekuen. Menurut Richard De George, bila perusahaan ingin sukses/berhasil memerlukan 3 hal pokok yaitu :

1. Memiliki produk yang baik

2. Memiliki managemen yang baik

3. Memiliki Etika

\section{Kendala Pencapaian tujuan etika bisnis di Indonesia}

Keraf (1993:81-83) menyebut beberapa kendala tersebut yaitu:

1. Standar moral para pelaku bisnis pada umumnya masih lemah. Banyak di antara pelaku bisnis yang lebih suka menempuh jalan pintas, bahkan menghalalkan segala cara untuk memperoleh keuntungan dengan mengabaikan etika bisnis, seperti memalsukan campuran, timbangan, ukuran, menjual barang yang kadaluwarsa, dan memanipulasi laporan keuangan

2. Banyak perusahaan yang mengalami konflik kepentingan. Konflik kepentingan ini muncul karena adanya ketidaksesuaian antara nilai pribadi yang dianutnya atau antara peraturan yang berlaku dengan tujuan yang hendak dicapainya, atau konflik antara nilai pribadi yang dianutnya dengan praktik bisnis yang dilakukan oleh sebagian besar perusahaan lainnya, atau antara kepentingan perusahaan dengan kepentingan masyarakat. Orang-orang yang kurang teguh standar moralnya bisa jadi akan gagal karena mereka mengejar tujuan dengan mengabaikan peraturan.

3. Situasi politik dan ekonomi yang belum stabil. Hal ini diperkeruh oleh banyaknya sandiwara politik yang dimainkan oleh para elit politik, yang di satu sisi membingungkan masyarakat luas dan di sisi lainnya memberi kesempatan bagi pihak yang mencari dukungan elit politik guna keberhasilan usaha bisnisnya. Situasi ekonomi yang buruk tidak jarang menimbulkan spekulasi untuk memanfaatkan peluang guna memperoleh keuntungan tanpa menghiraukan akibatnya.

4. Lemahnya penegakan hukum. Banyak orang yang sudah divonis bersalah di pengadilan bisa bebas berkeliaran dan tetap memangku jabatannya di pemerintahan. Kondisi ini mempersulit upaya untuk memotivasi pelaku bisnis menegakkan norma-norma etika.

5. Belum ada organisasi profesi bisnis dan manajemen untuk menegakkan kode etik bisnis dan manajemen. Organisasi seperti KADIN beserta asosiasi perusahaan di bawahnya belum secara khusus menangani penyusunan dan penegakkan kode etik bisnis dan manajemen.

\section{Etika Bisnis Dalam Hubungan Kerja.}

1. Perjanjian Kerja

Berdasarkan Pasal 56 Undang-Undang Nomor 13 Tahun 2003 tentang Ketenagakerjaan ("UU No.13/2003”), terdapat 2 (dua) jenis perjanjian kerja, yaitu Perjanjian Kerja Waktu Tertentu Dan Perjanjian Kerja Waktu Tidak Tertentu. 
a. Perjanjian Kerja Waktu Tertentu

Perjanjian kerja untuk waktu tertentu yang sering disebut dengan karyawan kontrak, dibuat berdasarkan jangka waktu tertentu atau berdasarkan selesainya pekerjaan tertentu. Klausul ini untuk memenuhi syarat suatu hal tertentu seperti dalam syarat umum sahnya perjanjian, yaitu obyeknya ditentukan berdasarkan "waktu pekerjaan" atau "selesainya pekerjaan". Obyek tersebut menurut jenis, sifat dan kegiatannya selesai dalam waktu tertentu dan tidak bersifat tetap.

b. Perjanjian Kerja Waktu Tidak Tertentu

PKWTT merupakan perjanjian yang tidak ditentukan waktunya dan bersifat tetap. Berbeda dengan PKWT yang wajib dibuat secara tertulis dan didaftarkan di instansi ketenagakerjaan terkait, selain tertulis PKWTT dapat dibuat secara lisan dan tidak wajib mendapat pengesahan dari instansi ketenagakerjaan terkait. Jika PKWTT dibuat secara lisan, maka klausul-klausul yang berlaku diantara mereka (Perusahaan dan Karyawan) adalah klausul-klausul sebagaimana yang diatur dalam UU Ketenagakerjaan Perusahaan dan Karyawan dianggap menyetujui UU Ketenagakerjaan sebagai "sumber perikatan" mereka.

2. Unsur-Unsur dalam Perjanjian Kerja

Berdasarkan pengertian perjanjian kerja diatas, dapat ditarik beberapa unsur dari perjanjian kerja, yakni :

a. Adanya Unsur Work atau Pekerjaan

Dalam suatu perjanjian kerja harus ada pekerjaan yang diperjanjikan (objek perjanjian), pekerjaan tersebut haruslah dilakukan sendiri oleh pekerja, hanya dengan seizin majikan dapat menyuruh orang lain.

b. Adanya Unsur Perintah

Manifestasi dari pekerjaan yang diberikan kepada pekerja oleh pengusaha adalah pekerja yang bersangkutan harus tunduk pada perintah pengusaha untuk melakukan pekerjaan sesuai dengan yang diperjanjikan. Di sinilah perbedaan hubungan kerja dengan hubungan lainnya.

c. Adana Unsur Upah

Upah memegang peranan penting dalam hubungan kerja, bahkan dapat dikatakan bahwa tujuan utama orang bekerja pada pengusaha adalah untuk memperoleh upah. Sehingga jika tidak unsur upah, maka suatu hubungan tersebut bukan merupakan hubungan kerja.

3. Berakhirnya Perjanjian Kerja

Definisi perjanjian kerja menurut Pasal 1 angka 14 Undang-Undang Nomor 13 Tahun 2003 tentang Ketenagakerjaan (“UU Ketenagakerjaan”) adalah perjanjian antara pekerja/buruh dengan pengusaha atau pemberi kerja yang memuat syarat-syarat kerja, hak dan kewajiban para pihak. Dari definisi tersebut dapat disimpulkan bahwa perjanjian kerja harus dipatuhi dan dilaksanakan oleh para pihak yang membuatnya. Namun, perjanjian kerja pun dapat diakhiri bilamana:

a. pekerja meninggal dunia;

b. berakhirnya jangka waktu perjanjian kerja;

c. adanya putusan pengadilan dan/atau putusan atau penetapan lembaga penyelesaian perselisihan hubungan industrial yang telah mempunyai kekuatan hukum tetap; atau 
d. adanya keadaan atau kejadian tertentu yang dicantumkan dalam perjanjian kerja, peraturan perusahaan, atau perjanjian kerja bersama yang dapat menyebabkan berakhirnya hubungan kerja

\section{METODE PENELITIAN}

Dalam artikel ini menggunakan metode analisis deskriptif kualitatif. Peneliti menggunakan metode penelitian kualitatif deskriptif ini agar peneliti dapat menggali informasi sedalam-dalamnya dan secermat mungkin untuk menganalisis penerapan etika bisnis pada PT SUCACO Tbk. Subjek pada penelitian ini adalah PT SUCACO Tbk. yang berada di Kalideres, Jakarta Barat. Objek penelitian pada penelitian kali ini adalah penerapanpenerapan etika bisnis pada PT SUCACO Tbk.

\section{HASIL DAN PEMBAHASAN}

\section{Profil Perusahaan}

PT SUCACO Tbk merupakan perusahaan manufaktur kabel yang didirikan pada 9 November 1970 dan mulai beroperasi pada 2 Oktober 1972 dengan bantuan teknis dari perusahaan Jepang, yaitu Furukawa Electric Co., Ltd. Tokyo, Jepang. Jenis kabel yang pertama kali diproduksi di PT SUCACO Tbk. Adalah kabel tegangan rendah (low voltage cable). Saat ini sudah memiliki berbagai macam jenis kabel seperti medium voltage, high voltage, telephone cable, fiber optic cable, LAN cable, twisted cable, dan, enameled wire. Seiring berkembangnya perusahaan, sampai saat ini PT SUCACO Tbk. memiliki 5 plant yang berada di Tangerang, Balaraja, Kalideres, Cikarang, dan Bekasi.

\section{Visi dan Misi PT SUCACO Tbk.}

Visi

Menjadi perusahaan kabel listrik terbesar di Indonesia dengan reputasi global.

Misi

1. Mencapai kinerja terbaik diantara produsen sejenis di Indonesia dalam hal keandalan produk, pangsa pasar, dan profitabilitas.

2. Memiliki kemampuan operasional dan daya saing yang kuat dalam melayani pasar Internasional.

3. Menjadi bagian dari usaha-usaha dalam membantu meningkatkan kualitas hidup masyarakat.

\section{Etika Bisnis PT SUCACO Tbk}

1. Sumber Daya Manusia

a. Integritas

Integritas adalah konsistensi dan keteguhan dalam menjunjung tinggi kejujuran dan nilai-nilai luhur yang diterapkan secara menyeluruh dalam setiap jajaran Perseroan dalam melaksanakan kegiatan usaha Perseroan. Dalam upaya mencapai visi Perseroan yaitu untuk menjadi produsen kabel listrik terbesar di Indonesia dengan reputasi global, maka penentuan arah kebijakan Perseroan serta setiap pengambilan keputusan dalam Perseroan, harus dilakukan dengan semangat menjaga integritas Perseroan. Setiap Karyawan dalam Perseroan wajib melaksanakan tugas-tugasnya dengan penuh integritas untuk mewujudkan misi Perseroan yaitu: 
1) Mencapai kinerja terbaik di antara produsen sejenis di Indonesia dalam hal keandalan produk, pangsa pasar dan profitabilitas;

2) Memiliki kemampuan operasional dan daya saing yang kuat dalam melayani pasar internasional;

3) Menjadi bagian dari usaha-usaha dalam membantu meningkatkan kualitas hidup masyarakat.

b. Patuh terhadap kebijakan dan peraturan Perseroan

Segenap Karyawan Perseroan wajib menjaga segala tindakan dan keputusan yang dibuatnya untuk selalu patuh terhadap kebijakan dan Peraturan Perseroan, baik dalam melaksanakan tugastugasnya di dalam Perseroan maupun tindakan-tindakannya di luar Perseroan. Kebijakan dan peraturan Perseroan yang dimaksud adalah Anggaran Dasar Perseroan, Peraturan Perseroan, Kode Etik Perseroan, Keputusan dan Kebijakan Manajemen Perseroan, Pedoman Kerja, Standard Operating Procedure, Standar Mutu Perseroan, serta tata cara penyelesaian tugas-tugas yang dipercayakan kepadanya. Pelanggaran terhadap kebijakan dan peraturan Perseroan dapat dikenakan sanksi sesuai keputusan Perseroan yang dapat berupa pengurangan jam kerja bahkan pemutusan hubungan kerja.

c. Menghindari konflik kepentingan

Seluruh Karyawan Perseroan harus menghindari situasi yang dapat menyebabkan konflik kepentingan antara kepentingan pribadi dengan kepentingan Perseroan. Prinsip menghindari konflik kepentingan ini harus diimplementasikan oleh Karyawan dalam hubungannya dengan Perseroan.

d. Hak individu

Perseroan senantiasa menjunjung tinggi hak setiap individu di dalam Perseroan. Dalam pelaksanaan hak dan kewajibannya di Perseroan, setiap Karyawan berhak mendapatkan perlakuan yang adil tanpa diskriminasi baik langsung maupun tidak langsung berdasarkan ras, warna kulit, jenis kelamin, agama, aliran politik, suku dan status sosial. Setiap Karyawan Perseroan berhak menjalankan ibadah berdasarkan agama dan kepercayaan masing-masing tanpa dihalang-halangi pihak manapun. Setiap Karyawan Perseroan berhak menerima upah kerja, tunjangan, serta hak lain sesuai dengan peraturan perundang-undangan serta perjanjian kerja antara Karyawan bersangkutan dengan Perseroan.

2. Komitmen terhadap Mitra Kerja dan Pelanggan

a. Kerahasiaan informasi pihak lain

Demi menjaga nama baik Perseroan, maka Karyawan wajib melindungi segala bentuk informasi milik pihak-pihak lain yang diketahuinya. Untuk itu Karyawan tidak berhak menyebarluaskan informasi sebelum diketahui/disepakati secara formal oleh kedua belah pihak yang terlibat, atau yang berdasarkan komitmen dengan pihak-pihak lain harus dirahasiakan.

b. Informasi orang dalam

Informasi orang dalam merupakan informasi material yang penting dan relevan mengenai peristiwa, kejadian atau fakta yang dapat mempengaruhi Perseroan, yang mana informasi ini belum tersedia untuk umum. Setiap Karyawan Perseroan dilarang untuk memanfaatkan informasi orang dalam untuk kepentingan pribadinya atau menginformasikan informasi orang dalam kepada pihak lain tanpa ijin tertulis dari Perseroan. 
c. Larangan untuk menerima pemberian hadiah dari pihak luar

1) Hadiah/Bingkisan/Gratifikasi

Perseroan tidak menyetujui pemberian atau penerimaan, segala bentuk hadiah/bingkisan/gratifikasi dalam bentuk apa pun kepada/dari pihak-pihak lain sebagai bentuk balas jasa atau ungkapan simpati sehubungan dengan pekerjaan/jabatan Karyawan di dalam Perseroan, termasuk menawarkan atau meminta hadiah/bingkisan/gratifikasi tersebut. Setiap penerimaan hadiah/bingkisan/gratifikasi dari pihak luar sehubungan dengan pekerjaan/jabatan Karyawan di Perseroan, wajib dilaporkan kepada atasan Karyawan yang bersangkutan.

2) Entertainment

Entertainment hanya dapat dilakukan oleh pejabat/Karyawan untuk kepentingan Perseroan dan dilaksanakan sesuai dengan ketentuan yang berlaku serta tidak bertentangan dengan nilai-nilai Perseroan.

3) Penyuapan

Perseroan melarang adanya penyuapan dalam berbagai bentuk. Penyuapan adalah usaha yang dilakukan oleh pihak-pihak lain kepada Karyawan dan/atau sebaliknya dengan tujuan mempengaruhi pengambilan keputusan dan dilakukan semata-mata demi kepentingan/keuntungan pribadi kedua belah pihak. Termasuk di dalam penyuapan adalah penerimaan maupun pemberian imbalan atau iming-iming dalam arti seluas-luasnya, baik berupa uang, barang, jasa, fasilitas-fasilitas atau kemudahan-kemudahan lainnya, dengan dan/atau tanpa melalaikan prosedur dan hukum yang berlaku dalam penyelesaian suatu urusan.

\section{KESIMPULAN}

Kesimpulan yang dapat diambil dari pembahasan diatas bahwa PT SUCACO Tbk. Menjalankan bisnis etik dengan adanya komitmen yang harus dijalani oleh perusahaan terhadap setiap elemen. Komitmen yang dijalankan oleh PT SUCACO Tbk. sebagai bentuk penjalan etika bisnis yaitu komitmen pada sumber daya manusia, komitmen terhadap mitra kerja dan pelanggan. PT SUCACO Tbk. Memusatkan etika bisnisnya terhadap peraturan-peraturan hukum yang berlaku serta berusaha menghindari adanya konflik.

\section{DAFTAR RUJUKAN}

Ali Hapzi. 2016. Concepts and Theories of Business Ethics. Universitas Mercu Buana.

Dermawan. 2017. Business Ethics and Good Governance Etika Bisnis pada PT Bank Mandiri Tbk. Jakarta

Nuryani Rima. Makalah Etika Bisnis. Diakses pada 17 Oktober 2019, dari https://www.academia.edu/31589119/MAKALAH_ETIKA_BISNIS

Riadi Muchlisin. 31 Oktober 2016. Pengertian, Prinsip dan Manfaat Etika Bisnis. Diakses pada 17 Oktober 2019, dari https://www.kajianpustaka.com/2016/10/pengertian prinsip-dan-manfaatetika-bisnis.html.

Ridho M.A. 2018. Bisnis Etik Pertamina Persero. Universitas Mercu Buana. Jakarta

Salmadian. 8 April 2018. Pengertian Etika Bisnis: Prinsip, Tujuan dan Contoh

Pelanggarannya. Diakses pada 17 Oktober 2019, dari

https://salamadian.com/pengertian-etika-bisnis/ 